\title{
Comparison of Prices and Affordability of Cancer Medicines in 16 Countries in Europe and Latin America
}

\author{
Daniela Moye-Holz ${ }^{1}$ (i) $\cdot$ S. Vogler ${ }^{2}$
}

Accepted: 15 June 2021 / Published online: 6 July 2021

(c) The Author(s) 2021

\begin{abstract}
Background There are concerns that high prices of cancer medicines may limit patient access. Since information on prices for cancer medicines and their impact on affordability is lacking for several countries, particularly for lower income countries, this study surveys prices of originator cancer medicines in Europe and Latin America and assesses their affordability. Methods For 19 cancer medicines, public procurement and ex-factory prices, as of 2017, were surveyed in five Latin American (LATAM) countries (Brazil, Chile, Colombia, Mexico, and Peru) and 11 European countries (Austria, France, Germany, Greece, Hungary, the Netherlands, Poland, Romania, Spain, Sweden, and the UK). Price data (public procurement prices in LATAM and ex-factory prices in Europe) in US dollar purchasing power parities (PPP) were analyzed per defined daily dose. Affordability was measured by setting medicines prices in relation to national minimum wages.

Results The prices of cancer medicines varied considerably between countries. In European countries with higher levels of income, PPP-adjusted prices tended to be lower than in European countries of lower income and LATAM countries. Except for one medicine, all surveyed medicines were considered unaffordable in most countries. In European countries of lower income and LATAM countries, more than 15 days' worth of minimum wages would be required by a worker to purchase one defined daily dose of several of the studied medicines.

Conclusions The high prices and large unaffordability of cancer medicines call for strengthening pricing policies with the aim of ensuring affordable treatment in cancer care.
\end{abstract}

\section{Introduction}

Cancer is a leading cause of mortality worldwide [1]. In middle-income (MICs) and high-income (HICs) countries cancer contributes to a considerable burden of disease [2-4]. Worldwide, MICs account for $68 \%$ of all deaths due to cancer, while HICs account for $29 \%$ [5]. This impacts the health systems in these countries as they aim

Daniela Moye-Holz

danymoyeholz@gmail.com; d.d.moye.holz@umcg.nl

S. Vogler

sabine.vogler@goeg.at

1 Department of Community and Occupational Medicine, University Medical Center Groningen, University of Groningen, Hanzeplein 1, 9713 GZ Groningen, The Netherlands

2 WHO Collaborating Centre for Pharmaceutical Pricing and Reimbursement Policies, Pharmacoeconomics Department, Gesundheit Österreich GmbH (GÖG/Austrian National Public Health Institute), Stubenring 6, 1010 Vienna, Austria

\section{Key Points for Decision Makers}

Lower-income countries tend to pay higher PPP-adjusted cancer medicine prices than countries with higher income. Given high PPP-adjusted prices, cancer medicines are largely unaffordable in Latin America and also Europe, in particular in countries of lower income.

These study findings point to more affordable cancer medicine prices in countries with national pricing policies to enhance patient access as a result of policy action to ensure coverage.

Policymakers should consider the study results when they opt for external price referencing as a policy and define the reference countries for benchmarking. 
to guarantee sustainable access to cancer care with comprehensive pharmaceutical treatment as a key component [1, 6-10].

For many types of cancers, pharmaceutical treatment accounts for a considerable share of healthcare expenditure [11-13]. Medicines exist for the treatment of most oncology diseases, and additional new medicines are expected to enter the market. Some medicines have provided better health outcomes, with fewer side effects [14], while the health benefits of other cancer medicines were assessed to be rather marginal [15-17].

Cancer medicines are usually expensive for both governments and patients [14, 18, 19]. Policymakers in MICs and HICs have been applying a mix of pricing and reimbursement policies, including external price referencing (EPR), health technology assessments (HTAs), price negotiations, and managed entry agreements (MEAs), to maintain the financial sustainability of the system while using various policy tools to promote and encourage access to high-priced medicines, including cancer medicines [20-31].

Evidence suggests that there is not necessarily an association between the income of a country and its medicine price level as lower income countries can pay higher procurement prices than countries of higher income [32-36]. Medicine price studies tend to focus on HICs [32, 34, 37-41]. Although some price studies were conducted in MICs [42-46], medicine prices of MICs are much less in the focus of research. In particular, little is known about the differences in prices of cancer medicines between MICs and HICs. Therefore, this study surveys the prices of originator cancer medicines in some MICs and HICs to identify possible cross-country differences in prices and affordability.

\section{Materials and Methods}

\subsection{Selection of Countries}

The study included 16 countries in Latin America (LATAM) and Europe: five upper MICs (UMICs) and 11 HICs, according to the World Bank classification in 2017 [47]. Within the two regions, we aimed to select countries of different gross national income (GNI) per capita. All European countries included in the study were HICs (except for Romania), but we classified these countries into two groups related to income: a group consisting of Austria, France, Germany, the Netherlands, Sweden, and the UK whose GNI per capita ranked among the highest world-wide-hereafter referred to as upper HICs (UHICs); and a group consisting of Greece, Hungary, Poland,
Romania (a UMIC), and Spain with comparably lower income-hereafter referred to as lower HICs (LHICs). The five selected LATAM countries represent a mix of UMICs (with Chile as a HIC) that differ in economic data and welfare distribution (Table 1). The selection of the LATAM countries was also guided by the practical rationale of whether, or not, a country had access to medicine price data.

\subsection{Selection of Medicines}

In the study, prices of 19 medicines (13 active ingredients) for the treatment of breast cancer, leukemia, colorectal cancer, and renal cancer were surveyed and analyzed (Table 2). The selection of medicines was based on a previous study (pricing survey) conducted in Mexico in 2017. In that study [48], medicines were selected based on their clinical relevance confirmed by their inclusion in the national formulary, their reimbursement by the public health insurance, and their inclusion in national treatment guidelines. Additionally, acknowledging the dynamics in medicine prices following patent expiry, the current study aimed to focus on on-patent medicines; thus, medicines that were included were under patent protection in Mexico in 2017 (time of the survey). To ensure comparability, since few medicines (e.g., imatinib, mercaptopurine) had lost patent protection in some countries at the time of the analysis, only the originator versions were considered.

\subsection{Data Sources}

Prices for Mexico were collected in 2017 through a primary price data survey using the World Health Organization (WHO)/Health Action International (HAI) methodology $[48,49]$. The WHO/HAI methodology [50] is an internationally acknowledged tool for measuring medicine prices, availability and affordability. It surveys and analyzes government procurement prices and patient prices in the public and private sectors, and it studies the price components along the supply chain. Public procurement prices (also referred to as institutional prices) of medicines in the four other LATAM countries (Peru, Colombia, Brazil, and Chile) were sourced from publicly available repositories maintained by governments (Table 3) [51]. Price data of official national price lists and price databases in European countries were provided by the Pharma Price Information (PPI) service of the Austrian National Public Health Institute [51].

Affordability was measured by the minimum wage as reported by countries to the Organization for Economic Cooperation and Development (OECD) (Table 3) [52]. 
Table 1 Characteristics of the countries included in the study

\begin{tabular}{|c|c|c|c|c|c|c|c|}
\hline Country & Country code & Region & $\begin{array}{l}\text { World Bank } \\
\text { classification }\end{array}$ & GINI index & GNI per capita & $\begin{array}{l}\text { GDP (2017) } \\
\text { (US\$/1000.000) }\end{array}$ & $\begin{array}{l}\text { Daily } \\
\text { minimum } \\
\text { wage }\end{array}$ \\
\hline Austria & AT & Europe & UHIC & 30.5 & 45,440 & $416,595.67$ & 60.25 \\
\hline Brazil & $\mathrm{BR}$ & LATAM/SA & UMIC & 51.3 & 8580 & $2,055,505.50$ & 15.22 \\
\hline Chile & CL & LATAM/SA & LHIC & 47.7 & 13,610 & $277,075.94$ & 22.06 \\
\hline Colombia & $\mathrm{CO}$ & LATAM/SA & UMIC & 50.8 & 5830 & $309,191.38$ & 22.14 \\
\hline France & FR & Europe & UHIC & 32.7 & 37,970 & $2,582,501.31$ & 62.71 \\
\hline Germany & $\mathrm{DE}$ & Europe & UHIC & 31.7 & 43,490 & $3,677,439.13$ & 65.30 \\
\hline Greece & EL & Europe & LHIC & 36.0 & 18,090 & $200,288.28$ & 37.23 \\
\hline Hungary & $\mathrm{HU}$ & Europe & LHIC & 30.4 & 12,870 & $139,135.03$ & 30.84 \\
\hline Mexico & MX & LATAM/NA & UMIC & 43.4 & 8610 & $1,149,918.79$ & 8.85 \\
\hline Netherlands & NL & Europe & UHIC & 28.2 & 46,180 & $826,200.28$ & 69.96 \\
\hline Peru & $\mathrm{PE}$ & LATAM/SA & UMIC & 43.8 & 5970 & $211,389.27$ & 17.52 \\
\hline Poland & PL & Europe & LHIC & $31.1^{\mathrm{a}}$ & 12,710 & $524,509.57$ & 37.57 \\
\hline Romania & RO & Europe & UMIC & 35.9 & 9970 & $211,803.28$ & 28.65 \\
\hline Spain & $\mathrm{ES}$ & Europe & LHIC & 36.2 & 27,180 & $1,311,320.02$ & 49.40 \\
\hline Sweden & SE & Europe & UHIC & 29.2 & 52,590 & $538,040.46$ & 60.88 \\
\hline United Kingdom & UK & Europe & UHIC & 33.2 & 40,530 & $2,622,433.96$ & 57.93 \\
\hline
\end{tabular}

All values are expressed in US\$ and for the year 2017. We used the GINI Index to have a perspective on the levels of inequality across countries included in the study. The GNI per capita is the measure used by the World Bank Classification to categorize countries by level of income. GDP measures the market value of goods produced in a country.

GDP gross domestic product, GINI Gini coefficient, GNI gross national income, LATAM Latin America, LHIC lower high-income country, NA North America, SA South America, UHIC upper high-income country, UMIC upper middle-income country, US\$ United States dollars

Sources for: World Bank Classification-The World Bank (https://datahelpdesk.worldbank.org/knowledgebase/articles/906519-world-bankcountry-and-lending-groups)

GINI Index-The World Bank (https://data.worldbank.org/indicator/si.pov.gini)

GDP—The World Bank (https://data.worldbank.org/indicator/ny.gdp.mktp.cd)

Daily Minimum Wage-Organization for Economic Co-operation and Development (OECD) real minimum wages (https://stats.oecd.org/Index. aspx? DataSetCode=RMW) and the Wageindicator.org

${ }^{\text {a}}$ Poland's last reported GINI Index relates to 2015

\subsection{Specifications for Analysis}

The analyzed prices were public procurement prices as of 2017 in the LATAM countries, given the relevance of the procurement prices in their public health systems, and exfactory prices (list prices before any deduction of discounts) as of September 2017 in European countries.

Public procurement and ex-factory prices were made comparable by determining unit prices per defined daily dose (DDD). Due to the non-assignment of a DDD by the WHO Collaborating Centre for Drug Statistics Methodology, DDDs as reported by Germany were used (Table 3).

The prices of all medicines were converted into United States dollars (US\$) using conversion rates of purchasing power parities (PPP) (see Table 3), which is the number of units of a country's currency required to buy a product in the domestic market that US\$ would buy the same product in the USA $[51,53]$.
Affordability was measured by the number of daily minimum wages (of each country) required to purchase one DDD in the selected medicines. This calculation is a modified version of the affordability assessment outlined in the WHO/HAI methodology [50] that computes the median price of 1 month or one course of treatment of one medicine against the wage of the lowest-paid unskilled government worker (or the minimum wage) in a country.

Price and affordability comparisons were carried out through a descriptive statistical analysis.

\section{Results}

\subsection{Medicine Price Differences Between Countries}

In Europe, UHICs (Austria, Germany, UK, the Netherlands, France, and Sweden) reported lower PPP-adjusted prices than countries of lower income (LHICs: Romania, 
Table 2 Medicines included in the study and their characteristics

\begin{tabular}{lll}
\hline INN_medicine & Presentation & DDD (mg) \\
\hline Bevacizumab & $100 \mathrm{mg} / 4 \mathrm{~mL}, 1$ vial & 45 \\
Bevacizumab & $400 \mathrm{mg} / 16 \mathrm{~mL}, 1$ vial & 45 \\
Cetuximab & $100 \mathrm{mg} / 20 \mathrm{~mL}, 1$ vial & 65 \\
Dasatinib & $50 \mathrm{mg}, 60$ tablets & 120 \\
Everolimus & $10 \mathrm{mg}, 30$ tablets & 10 \\
Everolimus & $5 \mathrm{mg}, 30$ tablets & 10 \\
Imatinib & $100 \mathrm{mg}, 60$ tablets & 500 \\
Imatinib & $400 \mathrm{mg}, 30$ tablets & 500 \\
Mercaptopurine & $50 \mathrm{mg}, 25$ tablets & 175 \\
Nilotinib & $200 \mathrm{mg}, 112$ tablets & 600 \\
Panitimumab & $100 \mathrm{mg} / 5 \mathrm{~mL}, 1$ vial & 30 \\
Pazopanib & $200 \mathrm{mg}, 30$ tablets & 800 \\
Pazopanib & $400 \mathrm{mg}, 60$ tablets & 800 \\
Rituximab & $100 \mathrm{mg} / 10 \mathrm{~mL}, 2$ vial & 32 \\
Rituximab & $500 \mathrm{mg} / 50 \mathrm{~mL}, 1$ vial & 32 \\
Sorafenib & $200 \mathrm{mg}, 112$ tablets & 800 \\
Sunitinib & $12.5 \mathrm{mg}, 28 \mathrm{tablets}$ & 35 \\
Trastuzumab & $440 \mathrm{mg}, 20 \mathrm{~mL} \times 1$ vial & 20 \\
Trastuzumab & $150 \mathrm{mg}, 1$ vial & 20 \\
\hline
\end{tabular}

INN International Nonproprietary Name, $D D D$ defined daily dose, $m g$ milligram, $m L$ milliliter
Poland, Hungary, Spain, and Greece). All prices in UHICs remained below US\$300 PPP/DDD, while prices in some European LHICs and LATAM countries ranged from less than US\$50 PPP/DDD to more than US\$500 PPP/DDD. European UHICs showed lower prices than LATAM countries and LHICs, and the prices for different medicines did not vary as much compared to LHICs and LATAM countries. While some medicine prices in LATAM countries were similar to those in HICs, some other medicines had higher prices in LATAM countries than in HICs (Fig. 1).

Across all medicines, mercaptopurine $50 \mathrm{mg}$ showed the lowest prices (median: US\$10.85 PPP/DDD - Netherlands; minimum $(\min )=$ US $\$ 0.89$ PPP/DDD - Spain; maximum $(\max )=U S \$ 26.02 \mathrm{PPP} / \mathrm{DDD}-$ Colombia $)$ in all countries. Prices of imatinib $100 \mathrm{mg}$ (median $=$ US\$78.24 PPP/DDD - Colombia; $\min =$ US\$6.71 PPP/DDD - Peru, $\max =\mathrm{US} \$ 162.89$ PPP/DDD - Germany) and imatinib 400 $\mathrm{mg}$ (median $=\mathrm{US} \$ 87.51 \mathrm{PPP} / \mathrm{DDD} ; \mathrm{min}=\mathrm{US} \$ 11.54 \mathrm{PPP} /$ DDD - Peru, $\max =$ US\$189.10 PPP/DDD - Hungary) were also lower than other medicines, but they differed considerably between countries. For nilotinib $200 \mathrm{mg}$, pazopanib $200 \mathrm{mg}$, pazopanib $400 \mathrm{mg}$, rituximab $100 \mathrm{mg}$, and rituximab $500 \mathrm{mg}$, prices ranged from approximately US\$50 PPP/DDD to US\$200 PPP/DDD; for these medicines Poland reported the highest prices, while the lowest prices were reported for Mexico and Brazil. For most analyzed medicines, Sweden and the UK reported the lowest prices, while prices in Poland and Romania were among the highest.

Table 3 Data sources

\begin{tabular}{|c|c|}
\hline Indicators & Data source \\
\hline \multicolumn{2}{|c|}{ Medicine price data } \\
\hline Mexico & Primary data collected by the first author using the WHO/HAI methodology \\
\hline Peru & $\begin{array}{l}\text { General Directorate of Medicine Supplies and Drugs (Dirección General de Medicamentos Insumos y Drogas, DIGEMID) } \\
\text { (http://www.digemid.minsa.gob.pe/Main.asp?Seccion=705) }\end{array}$ \\
\hline Colombia & $\begin{array}{l}\text { Price Thermometer (Termómetro de Precios) (https://www.minsalud.gov.co/salud/MT/Paginas/termometro-de-precios. } \\
\text { aspx) }\end{array}$ \\
\hline Brazil & Health Price Bank (Banco de Preços em Saúde) (http://bps.saude.gov.br/login.jsf) \\
\hline Chile & ChileCompra (https://www.mercadopublico.cl/Home/BusquedaLicitacion) \\
\hline EU countries & $\begin{array}{l}\text { Pharma Price Information service of the Austrian Public Health Institute (https://ppri.goeg.at/pharma_price_information), } \\
\text { average wholesale margins for countries that regulate pharmacy purchasing prices to calculate ex-ex-factory prices: } \\
\text { "Regelung für die Vorgehensweise der Preiskommission für die Ermittlung des EU-Durchschnittspreises gemäß } \S 351 \mathrm{c} \\
\text { Abs. } 6 \text { und Abs. 9a ASVG" (Regulation for the Procedure of the Pricing Committee to Calculate the EU Average Price in } \\
\text { accordance to § 351c para. } 6 \text { and para. 9a Austrian Social Health Insurance Law) }\end{array}$ \\
\hline \multicolumn{2}{|l|}{ Other data } \\
\hline Minimum wage & $\begin{array}{l}\text { OECD's Real Minimum Wages (https://stats.oecd.org/Index.aspx?DataSetCode=RMW) } \\
\text { For Austria and Sweden: data of minimum real wage of the lowest-skilled worker from Wageindicator.org }\end{array}$ \\
\hline PPP & OECD's Purchasing Power Parities Indicator (https://data.oecd.org/conversion/purchasing-power-parities-ppp.htm) \\
\hline DDD values & $\begin{array}{l}\text { Germany's “Anatomisch-Therapeutisch-chemische Klassifikation mit Tagesdosen für den deutschen Arzneimittelmarkt” } \\
\text { (Anatomical Therapeutic Chemical (ATC) Classification of daily doses for the German pharmaceutical market) (https:// } \\
\text { www.wido.de/fileadmin/Dateien/Dokumente/Publikationen_Produkte/Arzneimittel-Klassifikation/wido_arz_atc_gkv-ai_ } \\
\text { 2017.pdf) }\end{array}$ \\
\hline
\end{tabular}

$D D D$ defined daily dose, EU European Union, HAI Health Action International, OECD Organization for Economic Co-operation and Development, $W H O$ World Health Organization 


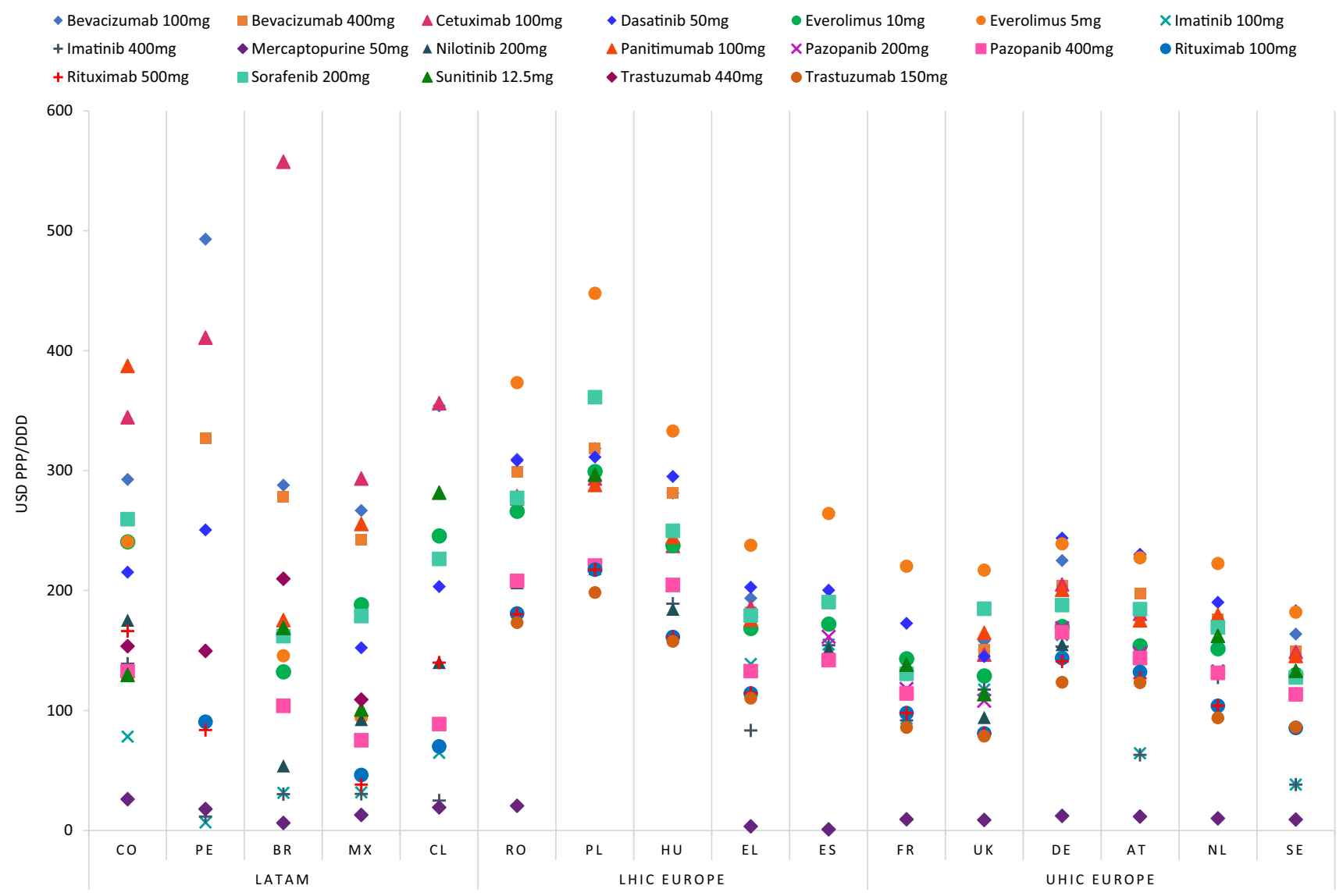

Fig. 1 Prices of originator cancer medicines in 11 European countries and five LATAM countries. DDD defined daily dose, LATAM Latin America(n countries), LHIC lower high-income countries, $m g$ milli-

For some medicines, Peru and Brazil reported the highest prices (e.g., bevacizumab $100 \mathrm{mg}$ and $400 \mathrm{mg}$, and cetuximab $100 \mathrm{mg}$; see also Online Supplemental Material: A1, $\mathrm{A} 2$, and $\mathrm{A} 3$ ).

\subsection{Affordability Differences Between Countries}

The affordability assessment showed that medicines were more affordable in HICs than in MICs (Fig. 2). For all medicines, less than 5 days' wages were required to purchase one DDD in all UHICs (median $=2.04$ days/ DDD), whereas the requirement increased to 5-13 days' wages in European LHICs (median $=6.79$ days/DDD). Across European countries, medicines were the least affordable (0.72-13.03 minimum wages) in Romania. In LATAM countries, for most medicines, 5 to more than 20 days' wages were required to buy one DDD of a medicine $($ median $=10.53$ days/DDD). Overall, medicines in Mexico were the least affordable (Online Supplemental Material: A4 and A5). grams, UHIC upper high-income countries, US\$ PPP/DDD price per medicine, adjusted to purchasing power parity (PPP) in US dollars per DDD, country code-see Table 1

Across all countries, mercaptopurine $50 \mathrm{mg}$ (median $=$ 0.19 day/DDD), trastuzumab $150 \mathrm{mg}$ (median $=1.97$ day $/$ DDD), imatinib $100 \mathrm{mg}$ (median $=2.06 \mathrm{day} / \mathrm{DDD})$, and imatinib $400 \mathrm{mg}$ (median $=2.01$ day/DDD) were the most affordable medicines. Eight medicines (bevacizumab 100 $\mathrm{mg}$, bevacizumab $400 \mathrm{mg}$, cetuximab $100 \mathrm{mg}$, dasatinib $50 \mathrm{mg}$, everolimus $5 \mathrm{mg}$, panitumumab $100 \mathrm{mg}$, sunitinib $12.5 \mathrm{mg}$, and trastuzumab $440 \mathrm{mg}$ ) reported the highest rates of unaffordability. For all other medicines, median affordability values ranged from 3 to up to nearly 5 days/ DDD (Online Supplemental Material: A4 and A5).

\section{Discussion}

The study shows price differences for originator cancer medicines between LATAM countries and European countries and across European countries of different income levels. In general, PPP-adjusted prices in HICs tended to be lower than in LICs. 


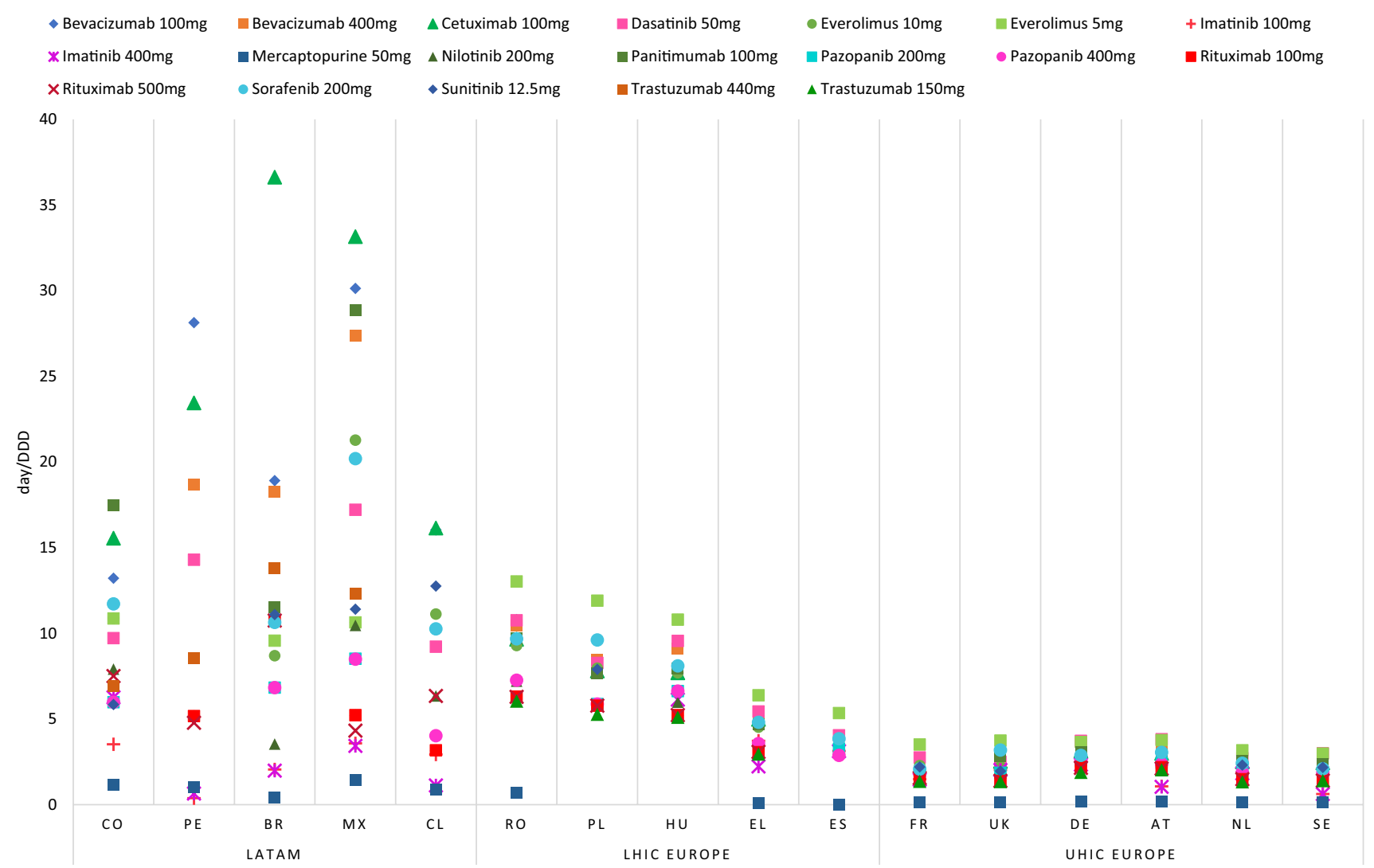

Fig. 2 Affordability of originator cancer medicines in 11 European countries and five LATAM countries. day/DDD number of daily minimum wages necessary to buy one DDD, $D D D$ defined daily

\subsection{Prices of Cancer Medicines}

Prices of all studied medicines differed between countries. Across Europe, PPP-adjusted prices in UHICs (France, Germany, the Netherlands, the UK, and Sweden) were lower than in LHICs (Spain, Poland, Hungary, Greece and Romania). Prices in European (UHIC and LHIC) countries were similar to or lower than in LATAM countries. This finding confirms previous research that could not identify any positive association between the income of a country and medicine prices [32-36, 54] and suggests a rather inverse relationship between country income and price (i.e., higher prices in LICs).

One explanation for high (PPP-adjusted) prices in LATAM countries compared to European HICs could be the lack of pricing and reimbursement policies, which had been implemented in European countries and have proven to be effective [26, 55-61]. In addition, given their willingness- and ability-to-pay, health systems of HICs can represent attractive markets for the pharmaceutical industry. In contrast, LHICs (Poland, Greece, Hungary, Romania, and Spain) are struggling with very tight budgets and are likely to have less power to bargain with manufacturers. These dose, LATAM Latin America(n countries), LHIC lower high-income countries, $m g$ milligram, UHIC upper high-income countries, country code—see Table 1

conclusions are in line with the findings of a cross-country comparison of prices of cancer medicines across Europe, which demonstrated that Central and Eastern European countries (i.e., those with lower incomes) were less able to negotiate discounts [62]. An analysis of list price and actual price data in that study [62] showed discounts of 53\% for two medicines in Italy and discounts between $30 \%$ and $40 \%$ for five medicines in Italy. Spain, Norway, and also Poland were also able to secure a discount in the range of 30-45\% for one or two medicines but in several cases discounts for these and further studied countries amounted to less than $10 \%$. No difference between the list price and the discounted price was reported for several medicines by some countries. An earlier study as of 2009 showed that for oncology medicines no or low discounts could be secured by hospital purchasers in five European countries, which was attributed to the fact that oncology medicines were monopoly medicines whereas for medicines with alternatives and with subsequent use in the outpatient sector larger discounts were provided [63]. The same pattern was confirmed in a report of the Austrian Court of Auditors, which identified higher discounts for cytostatic medicines with generics available compared to monoclonal antibodies (findings for two hospitals: average 
discounts of $13 \%$ and $17 \%$, respectively, for cytostatics in general, and of 7-8\% for monoclonal antibodies [64]).

Prices in LATAM countries showed considerably larger variation, with higher prices for several medicines compared to those in the studied European HICs. This can be the result of ineffective or lack of pricing regulations in these countries [25, 65, 66]. Colombia and Brazil control the prices of cancer medicines, while Peru and Chile have kept a free pricing system (i.e., no price regulation or control) [67, 68], and Mexico has a mixed system of free pricing in the private sector and price control through price negotiations in the public sector [27, 69]. As governments move on expanding health coverage, emerging markets with a large population size, like those in LATAM, could be considered attractive to the pharmaceutical industry [70, 71]. However, manufacturers do not offer prices of (originator) cancer medicines in line with the countries' income level [72]. This points to the necessity of government action to regulate medicine prices, since well-designed price regulation based on evidenceinformed selection through HTAs can help sustain medicine prices at more affordable levels [26, 58, 73-75].

A few active substances in the sample had gone off-patent at the time of the study, and the studied originator versions reported lower prices (e.g., imatinib and mercaptopurine). This highlights the impact of (generic) competition. Therefore, governments could use the efficiency gains of generic and biosimilar medicines and complement pricing policies by demand-side measures, such as generic substitution and information campaigns, to enhance the uptake of off-patent medicines [73].

This study adds to previous evidence that showed concerns about the high prices of cancer medicines $[3,15,16$, $18,19,76]$. It has been argued that their high prices are justified by the value that they bring. While some new cancer medicines have improved health outcomes, others have demonstrated limited evidence of their therapeutic value [15, $17,57,77,78]$.

\subsection{Affordability of Cancer Medicines}

In the literature, a medicine was defined as affordable if less than $20 \%$ of 1 day of income (minimum wage) is needed to buy one DDD [34, 48, 79]. According to this definition, nearly all surveyed medicines were unaffordable in the studied countries since, except for mercaptopurine in most HICs, in all countries at least more than 1 day's wage to procure one DDD would be required. These findings confirm the conclusions of a recent WHO report suggesting that prices of cancer medicines are unaffordable - to patients paying out of pocket, but very likely also to health systems globally [76].

There was large cross-country variation in the affordability of cancer medicines. While in the UHICs, less than
5 days' wages were required to procure one DDD of most medicines, the respective data for the LHICs in Europe and in LATAM countries were considerably higher (3-7 days' and 5 to more than 10 days' wages, respectively). The lowest affordability for most medicines was found in Mexico. Besides the price level, the unaffordability of cancer medicines in Mexico is also attributable to the country's minimum wage. If Mexico's minimum wage were as high as in Colombia, Peru, or Brazil, medicines would have been more affordable than in the other LATAM countries (see Online Supplemental Material: A6 and A7).

Governments have been implementing different policies to ensure access to high-priced medicines that would otherwise be unaffordable to their citizens. One of the solutions that has been used for cancer medicines in Europe and other HICs is MEAs [24, 31, 80]. MEAs can take different forms (e.g., flat discounts, risk-sharing agreements, price-volume agreements, pay-for-performance), but they have in common that lower prices are kept confidential [24, 38, 80, 81]. While these arrangements help to make medicines affordable for health systems, they negatively impact other countries that use EPR and reference to the officially (higher) published prices in these countries [24, 81]. The use of MEAs can also incentivize the pharmaceutical industry to set even higher prices of new products in expectation of a MEA [80, 82].

To improve access to new (cancer) medicines, governments have strengthened cross-country collaboration [83]. Supported by the European Commission, HTA bodies from several European countries have been working together in the European Network for HTA (EUnetHTA) project for over a decade. It fosters collaboration on HTAs by developing further methodologies and reducing overlaps and duplication of efforts. More formalized and sustainable collaboration beyond 2020 on HTAs is being discussed based on a European Commission proposal for a regulation of HTAs [84]. In addition, some cross-country collaborations of a few European countries (e.g., Baltic Procurement Initiative, Beneluxa Initiative, Nordic Pharmaceutical Forum, Valetta Declaration, and Fair and Affordable Pricing) have been established to collaborate on HTAs and horizon scanning, joint procurement, and joint negotiations [83, 85, 86]. These cross-country collaborations are rather new, and first successes (e.g., Beneluxa negotiation for nusinersen's price $[85,87])$ have focused so far on therapeutic areas other than cancer. For LATAM countries, the Pan-American Health Organization (PAHO) Strategic Fund has acted as a single entity negotiating and procuring prices of a defined set of medicines (including cancer medicines) and vaccines on behalf of participating member states [88]. PAHO's Strategic Fund has achieved prices lower or equivalent to international reference prices and other procuring agencies (e.g., the Clinton Foundation and the Global Fund); it has also provided better procurement conditions for a more efficient 
use of resources [88, 89]. However, these mechanisms have apparently not yet been sufficient to ensure affordability [49]. A possible reason could be that the pricing policies have not yet been designed in the most appropriate way to address national challenges, and more learnings on how to optimize the policy framework are needed. In addition, limitations of the policies' contribution to ensure affordability may also result from the high prices of cancer medicines in recent years that are an issue even for high-income countries with comparably lower PPP-adjusted prices [1, 3, 24, 25].

\subsection{Limitations}

Our study has some limitations. The ex-factory prices used might not be the actual prices paid, as many European countries concluded MEAs and other confidential arrangements for cancer medicines to obtain discounts. However, as discussed, there are indications that no or low discounts are granted for monopoly oncology medicines.

For the selection of the medicines, Mexico was taken as the starting point. We checked the applicability of the inclusion criteria (e.g., clinical relevance, on-patent status) only for this country and not for all other comparator countries. We acknowledge that a few medicines in a few countries had lost patent protection and this can have an impact on medicine prices, even on originator medicines that were surveyed.

We acknowledge that the WHO/HAI methodology was developed as an instrument for price surveys and affordability measurements in LICs where no medicine price information was published. However, the WHO/HAI methodology is not limited to low-income settings, and the affordability assessments have also been conducted in HICs [32, 90].

\subsection{Implications}

Findings of international medicine price and affordability comparisons provide evidence for policymakers to adapt and tailor policies towards affordable prices according to the country's characteristics [33, 35]. Knowledge about price levels in other countries is needed for methodological decisions on EPR to assess the appropriateness of the selection of comparator countries. The WHO Guideline on Country Pharmaceutical Pricing Policies, as updated in 2020, recommends selecting reference countries based on a set of explicitly stated factors, mentioning comparability such as in terms of market size, national income, and purchasing power [91]. If MICs choose HICs as their external reference benchmark without any adjustment for purchasing power parities, this might have catastrophic effects on prices and eventually on public budgets and patients who have to co-pay or fully pay out-of-pocket.

Affordability considerations (i.e., budget impact analyses) can constitute a valuable part of an HTA, in addition to the evidence on the additional therapeutic value of a medicine.

By comparing different countries and regions, the findings of this study on prices and affordability can inform the international community in their efforts to develop new models towards fair prices-those that provide a reasonable return of investment at a price that "does not bankrupt health systems" and does not cause "financial toxicity" $[54,92]$. The key findings of this study-prices for cancer medicines are variable and largely unaffordable-call upon policymakers to revise their policy framework and develop adequate policy options. There is specific need for policy action in UMICs since they are excluded from "access programs" that LICs enjoy. Furthermore, UMICs can suffer from trade pressure that HICs exercise to intensify intellectual property protection, and overall, these countries receive little international support to promote lower prices of medicines [93].

\section{Conclusions}

Public procurement and ex-factory prices of originator cancer medicines considerably differ between countries of different income levels and would be largely unaffordable compared to the national minimum wage. For several studied medicines their PPP-adjusted prices were higher in countries of lower income than in those of higher income.

High unaffordability levels constitute a major barrier to access to needed cancer care. Policymakers are urged to implement policies aiming at prices deemed affordable as well as ensuring coverage and public funding for medicines that demonstrate added value. Since access to affordable medicines is a global challenge, collaboration between countries and action at a global level is encouraged to move towards prices that are fair and sustainable for patients, health systems, and the industry.

Supplementary Information The online version contains supplementary material available at https://doi.org/10.1007/s40258-021-00670-4.

Acknowledgements We want to thank Peter Schneider of the Pharma Price Information (PPI) service at the Austrian National Public Health Institute for his contribution and support during the collection of price data of European countries.

\section{Declarations}

Funding None reported.

Conflict of interest All authors declare that they have no conflict of interest. 
Availability of data and material All data generated or analyzed during this study are included in this published article (and its Online Supplementary Material files).

Author contributions All authors contributed to the study conception and design. Material preparation, data collection and analysis were performed by DM-H. The first draft of the manuscript was written by DM-H. SV revised, supervised, and edited the drafts of the manuscript. All authors commented on previous versions of the manuscript. All authors read and approved the final manuscript.

Ethics approval Not applicable.

Consent to participate Not applicable.

Consent for publication Not applicable.

Code availability Not applicable.

Open Access This article is licensed under a Creative Commons Attribution-NonCommercial 4.0 International License, which permits any non-commercial use, sharing, adaptation, distribution and reproduction in any medium or format, as long as you give appropriate credit to the original author(s) and the source, provide a link to the Creative Commons licence, and indicate if changes were made. The images or other third party material in this article are included in the article's Creative Commons licence, unless indicated otherwise in a credit line to the material. If material is not included in the article's Creative Commons licence and your intended use is not permitted by statutory regulation or exceeds the permitted use, you will need to obtain permission directly from the copyright holder. To view a copy of this licence, visit http://creativecommons.org/licenses/by-nc/4.0/.

\section{References}

1. Stewart BW, Wild CP. World Cancer Report 2014. Lyon; 2014.

2. Strasser-Weippl K, Chavarri-Guerra Y, Villarreal-Garza C, Bychkovsky BL, Debiasi M, Liedke PER, et al. Progress and remaining challenges for cancer control in Latin America and the Caribbean. Lancet Oncol. 2015;16:1405-38.

3. Sullivan R, Peppercorn J, Sikora K, Zalcberg J, Meropol NJ, Amir E, et al. Delivering affordable cancer care in high-income countries. Lancet Oncol. 2011;12:933-80.

4. OECD. Cancer Care. Assuring quality to improve survival. OECD Publishing; 2013.

5. International Agency for Research on Cancer. Global Cancer Observatory [Internet]. [cited 2019 Apr 5]. Available from: https://gco.iarc.fr/.

6. Moten A, Schafer D, Farmer P, Kim J, Ferrari M. Redefining global health priorities: improving cancer care in developing settings. J Glob Health. 2014;4:1-5.

7. Farmer P, Frenk J, Knaul FM, Shulman LN, Alleyne G, Armstrong $\mathrm{L}$, et al. Expansion of cancer care and control in countries of low and middle income: a call to action. Lancet. 2010;376:1186-93.

8. Micheli A, Coebergh JW, Mugno E, Massimiliani E, Sant M, Oberaigner W, et al. European health systems and cancer care. Ann Oncol. 2003;14:41-60.

9. Ferrario A. Time to entry for new cancer medicines: from European Union-wide marketing authorization to patient access in Belgium, Estonia, Scotland, and Sweden. Value Health. 2018;21:809-21. https://doi.org/10.1016/j.jval.2018.01.003.
10. Smith N, Meletiche D, Beckerman R. Impact of time to reimbursement of drug treatments for non-small cell lung on patient outcomes in Europe and Latin America. Value Health. 2017;20:A468.

11. Knaul FM, Frenk J, Shulman L, for the Global Task Force on Expanded Access to Cancer Care and Control in Developing Countries. Closing the cancer divide: a blueprint to expand access in low and middle income countries. Boston; 2011.

12. Luengo-Fernandez R, Leal J, Gray A, Sullivan R. Economic burden of cancer across the European Union: a population-based cost analysis. Lancet Oncol. 2013;14(12):1165-74. https://doi. org/10.1016/s1470-2045(13)70442-X

13. Meropol NJ, Schulman KA. Cost of cancer care: issues and implications. J Clin Oncol. 2007;25:180-6.

14. Suh GH. High medicine prices and poor affordability. Curr Opin Psychiatry. 2011;24:341-5.

15. Fojo T, Grady C. How much is life worth: cetuximab, non-small cell lung cancer, and the $\$ 440$ billion question. J Natl Cancer Inst. 2009;101:1044-8.

16. Aggarwal A, Fojo T, Chamberlain C, Davis C, Sullivan R. Do patient access schemes for high-cost cancer drugs deliver value to society? Lessons from the NHS Cancer Drugs Fund. Ann Oncol. 2017;28:1738-50.

17. Davis C, Naci H, Gurpinar E, Poplavska E, Pinto A, Aggarwal A. Availability of evidence of benefits on overall survival and quality of life of cancer drugs approved by European Medicines Agency: retrospective cohort study of drug approvals 20092013. BMJ. 2017;359:J4530. https://doi.org/10.1136/bmj.j4530

18. Prasad V, De Jesús K, Mailankody S. The high price of anticancer drugs: origins, implications, barriers, solutions. Nat Rev Clin Oncol. 2017;14:381-90. https://doi.org/10.1038/nrclinonc. 2017.31.

19. Abboud C, Berman E, Cohen A, Cortes J, DeAngelo D, Deininger $\mathrm{M}$, et al. The price of drugs for chronic myeloid leukemia (CML) is a reflection of the unsustainable prices of cancer drugs: from the perspective of a large group of CML experts. Blood. 2013;121:4439-42.

20. Lu CY, Lupton C, Rakowsky S, Babar Z-U-D, Ross-Degnan D, Wagner AK. Patient access schemes in Asia-pacific markets: current experience and future potential. J Pharm Policy Pract. 2015;8:1-12.

21. van de Vooren K, Curto A, Freemantle N, Garattini L. Market-access agreements for anti-cancer drugs. J R Soc Med. 2015;108:166-70.

22. Kaltenboeck A. Pharmaceutical products and their value: lessons learned and the path ahead. Value Health. 2020;23:P421-424.

23. Aaltonen K, Ragupathy R, Tordoff J, Reith D, Norris P. The impact of pharmaceutical cost containment policies on the range of medicines available and subsidized in Finland and New Zealand. Value Health. 2010;13:148-56. https://doi.org/10.1111/j. 1524-4733.2009.00598.x.

24. Pauwels K, Huys I, Vogler S, Casteels M, Simoens S. Managed entry agreements for oncology drugs: lessons from the European experience to inform the future. Front Pharmacol. 2017;8:171.

25. Vogler S, Paris V, Panteli D. Ensuring access to medicines: How to redesign pricing, reimbursement and procurement? Copenhagen: European Observatory on Health Systems and Policies; 2018.

26. Vogler S, Paris V, Ferrario A, Wirtz VJ, de Joncheere K, Schneider $\mathrm{P}$, et al. How can pricing and reimbursement policies improve affordable access to medicines? Lessons learned from European countries. Appl Health Econ Health Policy. 2017;15:307-21.

27. Moye-Holz D, van Dijk JP, Reijneveld SA, Hogerzeil HV. Policy approaches to improve availability and affordability of medicines in Mexico — an example of a middle income country. Glob Health. 2017;13:1-10. 
28. Bangalee V, Suleman F, Pharmaceu Sci GJ. An overview of medicine pricing policies that may be applicable to low-and middleincome countries. S Afr Glob J Pharm Sci. 2018;6:93-6.

29. Kaplan WA, Ashigbie PG, Brooks MI, Wirtz VJ. Comparison of medicines management strategies in insurance schemes in middle-income countries: four case studies. J Pharm Policy Pract. 2017; 10:1-9.

30. Sruamsiri R, Ross-Degnan D, Lu CY, Chaiyakunapruk N, Wagner AK. Policies and programs to facilitate access to targeted cancer therapies in Thailand. PLoS ONE. 2015;10:e0119945.

31. Tuffaha H, Scuffham P. Rare cancers, no rare solutions: risk sharing arrangements to reimburse medicines for rare cancers in Australia. Value Health. 2018;21:S110.

32. Iyengar S, Tay-Teo K, Vogler S, Beyer P, Wiktor S, de Joncheere $\mathrm{K}$, et al. Prices, costs, and affordability of new medicines for hepatitis $\mathrm{C}$ in 30 countries: an economic analysis. PLoS Med. 2016;13:e1002032.

33. Salmasi S, Lee KS, Ming LC, Neoh CF, Elrggal ME, Babar ZUD, et al. Pricing appraisal of anti-cancer drugs in the South East Asian, Western Pacific and East Mediterranean Region. BMC Cancer. 2017;17:1-11.

34. Khatib R, McKee M, Shannon H, Chow C, Rangarajan S, Teo $\mathrm{K}$, et al. Availability and affordability of cardiovascular disease medicines and their effect on use in high-income, middle-income, and low-income countries: An analysis of the PURE study data. Lancet. 2016;387:61-9.

35. Machado M, O'brodovich R, Krahn M, Einarson TR. International drug price comparisons: quality assessment. Rev Panam Salud Publica. 2011;29(1):46-51

36. Hawlik K, Devalière A. Access to High-priced Medicines in Hospital Settings in Europe a study in four European countries. Amsterdam; 2014. Available from: http://haiweb.org/wp-content/ uploads/2016/04/Access-to-High-priced-Medicines-in-the-Hospi tal-Sector.pdf.

37. Cuomo RE, Seidman RL, Mackey TK. Country and regional variations in purchase prices for essential cancer medications. BMC Cancer. 2017;17:1-10.

38. Vogler S, Vitry A, Babar ZUD. Cancer drugs in 16 European countries, Australia, and New Zealand: a cross-country price comparison study. Lancet Oncol. 2016;17:39-47.

39. Goldstein DA, Rosenbaum E, Clark J, Zhang J, Goldstein R, Fang F, et al. A global comparison of the cost of patented cancer drugs in relation to global differences in wealth. Oncotarget. 2017;8:71548-55.

40. Danzon PM, Furukawa MF. International prices and availability of pharmaceuticals in 2005. Health Aff. 2008;27:221-33.

41. Kanavos P, Ferrario A, Vandoros S, Anderson GF. Higher US branded drug prices and spending compared to other countries may stem partly from quick uptake of new drugs. Health Aff. 2013;32:753-61.

42. Cameron A, Bansal A, Dua T, Hill SR, Moshe SL, Mantel-Teeuwisse AK, et al. Mapping the availability, price, and affordability of antiepileptic drugs in 46 countries. Epilepsia. 2012;53:962-9.

43. Mendis S, Fukino K, Cameron A, Laing R, Filipe A, Khatib O, et al. The availability and affordability of selected essential medicines for chronic diseases in six low- and middle-income countries. Bull World Health Organ. 2007;85:279-88.

44. Cameron A, Roubos I, Ewen M, Mantel-Teeuwisse AK, Leufkens HGM, Laing RO. Differences in the availability of medicines for chronic and acute conditions in the public and private sectors of developing countries. Bull World Health Organ. 2011;89:412-21.

45. Ewen M, Zweekhorst M, Regeer B, Laing R. Baseline assessment of WHO's target for both availability and affordability of essential medicines to treat non-communicable diseases. PLoS ONE. 2017;12:e0171284.
46. Lopes G, Arrieta O, Bonelli P, Castano R, Sehdev S, Binder $\mathrm{L}$, et al. High-cost oncologic medication access: why is Latin America falling behind? Case study in non-small cell lung cancer (NSCLC). Value Health. 2015;18:A825.

47. The World Bank. World Bank Country and Lending Groups [Internet]. [cited 2019 Mar 26]. Available from: https://datah elpdesk.worldbank.org/knowledgebase/articles/906519-worldbank-country-and-lending-groups.

48. Moye-Holz D, Ewen M, Dreser A, Bautista-Arredondo S, SoriaSaucedo R, van Dijk JP, et al. Availability, prices, and affordability of selected essential cancer medicines in a middle-income country-the case of Mexico. BMC Heal Serv Res. 2020;20:1-11.

49. Moye-Holz D. Access to innovative medicines in a middle-income country. The Case of Mexico and Cancer Medicines. University of Groningen. Groningen, 2019.

50. World Health Organization. Health Action International. Measuring medicine prices, availability, affordability and price components. 2nd ed. World Health Organization; 2008. p. 293.

51. Vogler S. Medicine price surveys, analyses, and comparisons: evidence, methodology and guidance. 1st ed. Academic Press, 2019. https://doi.org/10.1016/C2016-0-04253-5

52. OECD . Real minimum wages [Internet]. OECD.Stat. [cited 2019 Mar 26]. Available from: https://stats.oecd.org/Index.aspx?DataS etCode $=$ RMW.

53. Suh GH, Wimo A, Gauthier S, O'Connor D, Ikeda M, Homma A, et al. International price comparisons of Alzheimer's drugs: A way to close the affordability gap. Int Psychogeriatrics. 2009;21:1116-26.

54. OECD. Addressing challenges in access to oncology medicines. Analytical Report. Paris; 2020.

55. Panteli D, Arickx F, Cleemput I, Dedet G, Eckhardt H, Fogarty E, et al. Pharmaceutical regulation in 15 European countries. Health Syst Transit. 2016;18(5):1-122.

56. WHO. Access to new medicines in Europe: technical review of policy initiatives and opportunities for collaboration and research. Copenhagen; 2015.

57. Fojo T, Lo AW. Price, value, and the cost of cancer drugs. Lancet Oncol. 2016;17:3-5.

58. Wettstein DJ, Boes S. Effectiveness of national pricing policies for patent-protected pharmaceuticals in the OECD: a systematic literature review. Appl Health Econ Health Policy. 2019;17:143-62. https://doi.org/10.1007/s40258-018-0437-z.

59. Carone G, Schwierz C, Xavier A, Commission E, General D, Affairs F. Cost-containment policies in public pharmaceutical spending in the EU. Brussels; 2012.

60. Vogler S, Martikainen JE. Pharmaceutical pricing in Europe. In: Babar ZUD. (eds) Pharmaceutical Prices in the 21st Century. Adis, Cham; 2014:343-70. https://doi.org/10.1007/978-3-31912169-7_19

61. Kawalec P, Tesar T, Vostalova L, Draganic P, Manova M, Savova A, et al. Pharmaceutical regulation in Central and Eastern European countries: a current review. Front Pharmacol. 2017;8:892.

62. van Harten WH, Wind A, de Paoli P, Saghatchian M, Oberst S. Actual costs of cancer drugs in 15 European countries. Lancet Oncol. 2016;17:18-20.

63. Sabine V, Nina Z, Christine L, Claudia H, Jan M. Discounts and rebates granted for medicines for hospital use in five European countries. Open Pharmacoecon Health Econ J. 2013;5:1-10.

64. Arzneimittelbeschaffung für ausgewählte Krankenanstalten in Salzburg und Tirol Vorbemerkungen [Procurement of medicines for selected hospitals in Salzburg and Tyrol]. Vienna; 2019.

65. OECD. New Health Technologies: Managing Access, Value and Sustainability. OECD Publ. Paris; 2017. https://doi.org/10.1787/ 9789264266438-en.

66. Council of the European Union. Council conclusions on strengthening the balance in the pharmaceutical systems in the EU and its 
Member States [Internet]. 2016 [cited 2019 May 17]. Available from: https://www.consilium.europa.eu/en/press/press-releases/ 2016/06/17/epsco-conclusions-balance-pharmaceutical-system/.

67. Espín Balbino J, Rovira Forns J, Vaca González C. Medicine Prices in Latin American Countries. In: Vogler S, editor. Medicine price surveys, analyses and comparisons. Evidence and methodology guidance. 1st ed. Academic Press; 2019. p. 61-83. https://doi. org/10.1016/B978-0-12-813166-4.00006-1

68. Gaviria A, Morales ÁA, Prada SI, Soto VE, Vaca CP, Andia TS, et al. Higher pharmaceutical public expenditure after direct price control: improved access or induced demand? The Colombian case. Cost Eff Resour Alloc. 2018;16:1-8.

69. Moye-Holz D, Van DJP, Reijneveld SA, Hogerzeil HV. The impact of price negotiations on public procurement prices and access to 8 innovative cancer medicines in a middle-income country-the case of Mexico. Value Heal Reg Issues. 2019;20:129-35. https:// doi.org/10.1016/j.vhri.2019.04.006.

70. Grunwald A. Challenges Of Optimizing Drug Pricing In Emerging Markets [Internet]. 2014 [cited 2018 Dec 26]. Available from: https://www.lifescienceleader.com/doc/challenges-of-optimizingdrug-pricing-in-emerging-markets-0001.

71. Mexico: growing South America's pharmaceutical industry. Pharm Technol Mark Cust Insight [Internet]. 2013 [cited 2018 Dec 26]; Available from: http://www.pharmaceuticaltechnology. com/features/featuremexicodrugspharmaceuticalbrazilsouthameri $\mathrm{ca} /$.

72. Danzon PM, Furukawa MF. Prices And Availability Of Pharmaceuticals: Evidence From Nine Countries. Health Aff. 2003; SupplW3-521-36. https://doi.org/10.1377/hlthaff.w3.521.

73. WHO. WHO Guideline on country pharmaceutical pricing policies. Geneva; 2015.

74. Wirtz VJ, Hogerzeil HV, Gray AL, Bigdeli M, de Joncheere CP, Ewen MA, et al. Essential medicines for universal health coverage. Lancet. 2017;389:403-76.

75. Nguyen TA, Knight R, Roughead EE, Brooks G, Mant A. Policy options for pharmaceutical pricing and purchasing: Issues for low- and middle-income countries. Health Policy Plan. 2015;30:267-80.

76. World Health Organization. Technical report: pricing of cancer medicines and its impacts: a comprehensive technical report for the World Health Assembly Resolution 70.12: operative paragraph 2.9 on pricing approaches and their impacts on availability and affordability of medicines for the prevention and treatment of cancer. World Health Organization. Geneva, 2018. Available at: https://apps.who.int/iris/handle/10665/277190.

77. Cohen D. Cancer drugs: high price, uncertain value. BMJ. 2017;359:1-4.

78. Vokinger KN, Hwang TJ, Grischott T, Reichert S, Tibau A, Rosemann T, et al. Prices and clinical benefit of cancer drugs in the USA and Europe: a cost-benefit analysis. Lancet Oncol. 2020;21:664-70.

79. Sarwar MR, Iftikhar S, Saqib A. Availability of anticancer medicines in public and private sectors, and their affordability by low, middle and highincome class patients in Pakistan. BMC Cancer. 2018;18:1-11.

80. Ferrario A, Kanavos P. Managed entry agreements for pharmaceuticals: The European experience. EMiNET. Belgium, 2013.
81. Ferrario A, Kanavos P. Dealing with uncertainty and high prices of new medicines: a comparative analysis of the use of managed entry agreements in Belgium, England, the Netherlands and Sweden. Soc Sci Med. 2015;124:39-47. https://doi.org/10.1016/j. socscimed.2014.11.003.

82. Gerkens S, Neyt M, San Miguel L, Vinck I, Thiry N, Cleemput I. How to improve the Belgian process for managed entry agreements? An analysis of the Belgian and international experience. KCE Report. Brussels; 2018.

83. Espín J, Rovira J, Calleja A, Azzopardi-Muscat N, Richardson E, Palm W, et al. How can voluntary cross-border collaboration in public procurement improve access to health technologies in Europe? [Internet]. Copenhaguen; 2016. Available from: http:// www.euro.who.int/pubrequest.

84. European Commission. Regulation of the European Parliament and of the Council on health technology assessment and amending Directive 2011/24/EU. Brussels; 2018.

85. Natsis Y. BENELUXA: First results of multi-country cooperation on medicine price negotiations Reflection Paper. Brussels; 2017.

86. Sabine V, Haasis MA, van den Ham R, Suleman F, Humbert T, Garner S. Cross-country collaboration to improve access to medicines and vaccines in the WHO European Region. Copenhagen; 2020.

87. Beneluxa. Archive. Positive outcome of joint reimbursement negotiations on Spinraza [Internet]. 2018 [cited 2019 Mar 26]. Available from: http://www.beneluxa.org/archive.

88. Horst MML de L, Soler O. Fundo Estratégico da Organização Pan-Americana da Saúde: mecanismo facilitador para melhorar o acesso aos medicamentos [Strategic Fund of the Pan American Health Organization: Facilitating Mechanism to Improve Access to Medicines]. Rev Panam Salud Pública. 2010;27(1):43-8.

89. DeRoeck D, Bawazir SA, Carrasco P, Kaddar M, Brooks A, Fitzsimmons $\mathbf{J}$, et al. Regional group purchasing of vaccines: Review of the Pan American Health Organization EPI revolving fund and the Gulf Cooperation Council group purchasing program. Int J Health Plan Manag. 2006;21:23-43.

90. Sharma A, Rorden L, Ewen M, Laing R. Evaluating availability and price of essential medicines in Boston area (Massachusetts, USA) using WHO/HAI methodology. J Pharm Policy Pract. 2016;9:12. https://doi.org/10.1186/s40545-016-0059-5.

91. World Health Organisation (WHO). WHO Guideline on Country Pharmaceutical Pricing Policies [Internet]. 2nd edition. Geneva; 2020. Available from: https://apps.who.int/iris/bitstream/handle/ 10665/335705/9789240011908-eng.pdf.

92. Van Berlage B. Report on the Fair Pricing Forum 2017 [Internet]. Geneva; 2017. Available from: http://apps.who.int/bookorders.

93. Radhakrishnan P. Commentary: making middle income countries pay full price for drugs is a big mistake. BMJ. 2015;351:h3757. 